\title{
Rural Workers Would Benefit More Than Urban Workers from an Increase in the Federal Minimum Wage
}

\author{
W ILLIAM O'HARE
}

A potential increase in the minimum wage is primarily seen as an urban issue, but data presented here illustrates that an increase in the minimum wage is every bit as important to rural workers as it is to those who live and work in major metropolitan areas of the nation.

In 1997, Congress raised the federal minimum wage to $\$ 5.15$ an hour and that is where it has stayed for ten years. Because of inflation, the real value of the minimum wage has eroded by nearly 20 percent during the last ten years. But on January 10, 2007, the U.S. House of Representatives passed legislation that would increase the minimum wage to $\$ 7.25$ an hour over the next two years. ${ }^{1}$ The U.S. Senate will address this issue soon and the President has indicated he is likely to support an increase in the minimum wage. ${ }^{2}$

This Carsey Institute Fact Sheet looks at how such an increase would impact rural ${ }^{3}$ workers relative to urban workers by examining workers who are likely to benefit directly from an increase in the minimum wage because they currently earn less than $\$ 7.25$ an hour. For ease of presentation, this group is called "low-wage workers." This analysis looks at 74 million hourly workers who represent about 60 percent of all workers.

It should be noted that workers earning less than $\$ 7.25$ an hour are not the only people who would benefit from an increase in the minimum wage. However, this analysis provides a reasonable reflection of the distributional aspects of the likely increase in the minimum wage. Other studies provide a more sophisticated analysis of the impact of the minimum wage, but they don't present the urban/rural differences. $^{4}$

Table 1 indicates that of the ten million workers who earn less than $\$ 7.25$ an hour, about 1.9 million live in rural America. Rural low-wage workers make up 19 percent of all low-wage hourly workers in America. A slightly higher share of rural workers than urban workers are in low-wage jobs (15.4 percent of all rural hourly workers compared to
13.5 percent in urban areas). More than 5.5 million people in rural America live in households where someone earns less than $\$ 7.25$ an hour.

The relatively large impact among rural workers is not surprising given past research that shows a large portion of rural workers employed at low-wage jobs and past studies on an increase in minimum wage showing that low-income families in small towns and isolated counties would benefit disproportionately from an increase in the minimum wage. ${ }^{5}$

Some argue that the minimum wage goes further in rural areas because the cost of living is lower. Certainly there are some price advantages to living in rural America, but the two sectors where prices have increased most rapidly since 2000 (energy by 42 percent and medical care by 24 percent) hit rural consumers as hard if not harder than urban consumers. ${ }^{6}$

Looking at demographic characteristics first, Table 1 shows that for females, young workers (under age 24), and married workers, the likelihood of being affected by the hike in the minimum wage are slightly higher for rural workers than for urban workers. The regional and racial distributions of low-wage workers are also quite different for rural and urban populations. Rural low-wage workers are much more concentrated in the Midwest, while urban low-wage workers are over-represented in the West. While 86 percent of low-wage workers in rural America are non-Hispanic whites, only 55 percent of low-wage workers in urban areas are non-Hispanic whites.

Looking at employment and economic characteristics, part-time workers in rural areas are more likely to be affected by the hike in the minimum wage than their urban counterparts. In the two occupations where low-wage jobs are most concentrated (service and sales, and office jobs), workers in rural areas are less likely than their urban counterparts to be in low-wage jobs. On the other hand, rural workers are over-represented in low-wage jobs in those

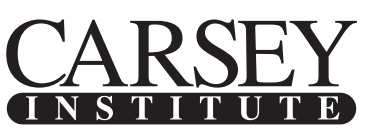

BUILDING KNOWLEDGE FOR FAMilies AND CoMmunities IN THE 21ST CENTURY
Huddleston Hall, 73 Main Street, Durham, NH 03824

(603) 862-2821 • www.carseyinstitute.unh.edu

The Carsey Institute Reports on Rural America are supported by the Annie E. Casey Foundation's initiative to strengthen rural families, the Ford Foundation, and the W.K. Kellogg Foundation. 
occupations that do not typically offer low wages. Looking at the distribution of workers by industry, rural workers are over-represented in Educational and Health Services lowwage jobs and under-represented in Leisure and Hospitality industries relative to their urban counterparts.

Low-wage workers are less likely than other hourly workers to have any form of health insurance. Nationwide, 21 percent of all hourly paid workers lack health insurance, but the figure is 35 percent for all low-wage workers. However, a greater percentage of urban low-wage workers lack health insurance (37 percent), compared with rural low-wage workers (28 percent).

Not surprisingly low-income families would benefit the most from an in crease in the minimum wage. In rural America, 52 percent of workers making less than $\$ 7.25$ an hour live in low-income families (less than $\$ 30,000$ a year) compared to 43 percent of urban low-wage workers

The data presented here make it is clear that an increase in the minimum wage to $\$ 7.25$ an hour would have a bigger impact in rural America than in urban America.

How the data is gathered. In the basic Monthly Current Population Survey conducted by the Census Bureau for the Bureau of Labor statistics, a subset of the respondents are asked if they are paid by the hour and what their hourly rate of pay is. In this study, we identified those who reported that they were making less than $\$ 7.25$ an hour in the March 2006 survey as the ones most likely to be directly affected by an increase in the minimum wage. A small number of workers (less than one-half of one percent) were not included in the study because the Census Bureau did not release their metropolitan status on the public use file in order to protect confidentiality. It is unlikely that the omission of this small number of people from the analysis would have any impact on the outcomes of the study.

\section{Endnotes}

${ }^{1}$ Weisman, Jonathan, 2007, "House Passes Increase in the Minimum Wage to \$7,25," The Washington Post, page A6, January 11, 2007.

${ }^{2}$ Fletcher, Michael A. and Jonathan Weisman, 2006, "Bush Supports Democrat' Minimum Wage Hike Plan,” The Washington Post, page A14, December 21, 2006.

${ }^{3}$ Here, "rural" refers to nonmetropolitan counties as classified by the U.S. Office of Management and Budget. Metropolitan counties consist essentially of one or more urbanized areas (e.g., cities) with a population of 50,000 or more, plus surrounding counties tied economically to the central city via community patterns. "Urban" here means "metropolitan."

${ }^{4}$ Economic Policy Institute, The Minimum Wage, Washington DC., available at http://www.epi.org/content.cfm/issueguides_minwage; and Sherk, James, 2006, Minimizing the Harm of the Minimum Wage, The Heritage Foundation, Washington, DC. http://www.heritage.org/ Research/GovernmentReform/upload/sr_11_4.pdf

${ }^{5}$ Glasmeier, Amy and Priscilla Salant, 2006, Low-Skill Workers in Rural America Face Permanent Job Loss, The Carsey Institute at the University of New Hampshire, Policy Brief, No. 2, Spring; and http://www.ers.usda.gov/publications/rdp/rdpmay99/rdpmay99b.pdf
Table 1. Workers Likely to be Affected by a CHANGE IN MiNiMUM WAGE

\begin{tabular}{|c|c|c|c|c|}
\hline & \multicolumn{4}{|c|}{ Workers Making Less Than $\$ 7.25$ an Hour } \\
\hline & \multicolumn{2}{|c|}{ Nonmetro } & \multicolumn{2}{|c|}{ Metro } \\
\hline & $\begin{array}{l}\text { Number } \\
\text { (in 1000s) }\end{array}$ & Percent & $\begin{array}{l}\text { Number } \\
\text { (in 1000s) }\end{array}$ & Percent \\
\hline All persons & 1,909 & 100 & 8,231 & 100 \\
\hline DEMOGRAPHICS & & & & \\
\hline Northeast & 255 & 13 & 1,224 & 15 \\
\hline Midwest & 737 & 39 & 1,756 & 21 \\
\hline South & 753 & 39 & 3,334 & 41 \\
\hline West & 165 & 9 & 1,917 & 23 \\
\hline Male & 674 & 35 & 3,319 & 40 \\
\hline Female & 1,235 & 65 & 4,912 & 60 \\
\hline Under age 24 & 966 & 51 & 4,029 & 49 \\
\hline Ages $24-29$ & 181 & 9 & 1,148 & 14 \\
\hline Ages 30-64 & 671 & 35 & 2,735 & 33 \\
\hline Ages 65+ & 91 & 5 & 319 & 4 \\
\hline Non-Hispanic White & 1,634 & 86 & 4,500 & 55 \\
\hline Non-Hispanic Black & 105 & 6 & 1,181 & 14 \\
\hline Hispanic & 95 & 5 & 2,018 & 25 \\
\hline All 0thers & 75 & 4 & 532 & 6 \\
\hline Married & 573 & 30 & 2,069 & 25 \\
\hline Divorced/Separated & 194 & 10 & 835 & 10 \\
\hline Widowed & 48 & 3 & 240 & 3 \\
\hline Never Married & 1,095 & 57 & 5,087 & 62 \\
\hline \multicolumn{5}{|l|}{ EMPLOYMENT AND INCOME } \\
\hline (35 or more hours/week) & 877 & 46 & 4,043 & 49 \\
\hline Part time & 1,033 & 54 & 4,189 & 51 \\
\hline \multicolumn{5}{|l|}{ Occupation } \\
\hline Service & 761 & 40 & 3,835 & 47 \\
\hline Sales & 357 & 19 & 1,859 & 23 \\
\hline Office and administrative & & & & \\
\hline support & 245 & 13 & 699 & 8 \\
\hline All 0ther 0ccupations & 546 & 29 & 1,838 & 22 \\
\hline \multicolumn{5}{|l|}{ Industry } \\
\hline Leisure and hospitality & 592 & 31 & 3,216 & 39 \\
\hline Wholesale and retail trade & 468 & 25 & 2,019 & 25 \\
\hline $\begin{array}{l}\text { Educational and } \\
\text { health services }\end{array}$ & 339 & 18 & 848 & 10 \\
\hline All other Industries & 511 & 27 & 2,149 & 26 \\
\hline No health Insurance & 540 & 28 & 3,016 & 37 \\
\hline \multicolumn{5}{|l|}{ Family income } \\
\hline Total with income reported & 1,607 & 100 & 6,905 & 100 \\
\hline Under $\$ 30,000$ & 829 & 52 & 2,950 & 43 \\
\hline$\$ 30,000-\$ 49,999$ & 320 & 20 & 1,489 & 22 \\
\hline$\$ 50,000$ or more & 459 & 29 & 2,466 & 36 \\
\hline
\end{tabular}

March 2006 Current Population Survey conducted by the U.S. Census Bureau.
${ }^{6}$ U.S. Statistical Abstract, Table 706. http://www.census.gov/compen$\mathrm{dia} /$ statab/tables/07s0706.xls 